\title{
THE LEADERSHIP OF HEADMASTER IN IMPROVING THE QUALITY OF MADRASA EDUCATION
}

\author{
Nursaid \\ Institut Agama Islam Negeri (IAIN) Imam Rijali Ambon \\ Jl. Dr. H. Tarmizi Taher, Kebun Cengkeh, Kota Ambon, Indonesia, 97128 \\ Email: nursaidngadingmail.com
}

Received: 10, 2018. Accepted: 06, 2020. Published: 06, 2020

\begin{abstract}
The Quality of madrasa education depends on many factors like the leadership of headmaster which is crucial and influential to other supporting factors in maintaining and securing quality education of madrasa. This paper was aimed at investigating the leadership of madrasa headmasters in improving the quality of madrasa education in Maluku Province. It also investigated the contribution of headmaster leadership toward the teachers' characteristic that contribute immensely to educational service. This study applied descriptive qualitative using a naturalistic approach. To achieve the objectives of the study, observations, interviews, and documentation were used in data collection techniques. The data collected were analysed using Miles and Huberman model. The study found that the leadership of headmaster has contributed to the improvement quality of madrasa education. The leaderships included many aspects like the ability to create, plan, organize and communicate within organization of madrasa. The headmaster leadership also played significant role in building the characteristics of teacher like theological trait, physical, intelligence and personal charcteristics. Those characteristics are pivotal in improving teachers' quality of educational service.
\end{abstract}

Keywords: Headmaster, Leadership, Quality of Madrasa Education

\begin{abstract}
ABSTRAK
Kualitas pendidikan madrasah tergantung pada banyak faktor seperti kepemimpinan kepala sekolah yang sangat penting dan berpengaruh terhadap faktor-faktor pendukung lainnya dalam menjaga dan mengamankan kualitas pendidikan madrasah. Makalah ini bertujuan untuk menyelidiki kepemimpinan kepala sekolah madrasah dalam meningkatkan kualitas pendidikan madrasah di Provinsi Maluku. Ini juga menyelidiki kontribusi kepemimpinan kepala sekolah terhadap karakteristik guru yang berkontribusi besar terhadap layanan pendidikan. Penelitian ini menggunakan deskriptif kualitatif dengan menggunakan pendekatan naturalistik. Untuk mencapai tujuan penelitian, observasi, wawancara, dan dokumentasi digunakan dalam teknik pengumpulan data. Data yang dikumpulkan dianalisis menggunakan model Miles dan Huberman. Studi ini menemukan bahwa kepemimpinan kepala sekolah telah berkontribusi pada peningkatan kualitas pendidikan madrasah. Kepemimpinan mencakup banyak aspek seperti kemampuan untuk membuat, merencanakan, mengatur, dan berkomunikasi dalam organisasi madrasah. Kepemimpinan kepala sekolah juga memainkan peran penting dalam membangun karakteristik guru seperti sifat teologis, fisik, kecerdasan, dan karakteristik pribadi. Karakteristik tersebut sangat penting dalam meningkatkan kualitas layanan pendidikan guru.
\end{abstract}

Kata Kunci: Kepala Madrasah, Kepemimpinan, Mutu Pendidikan Madrasah 


\section{INTRODUCTION}

Professional headmasters are expected to be able to manage madrasa as well as their quality output and outcome (Wiyoto, 2017; Maswan, 2015; Idris, 2009; Burhanuddin, et. al., 2016). They play an important role in continuously improving and developing madrasa (Yang, 2014; Munir, 2008). To carry out their mission in developing and improving the quality of madrasah education, the headmasters should possess adequate competence. In line with this, Wiyoto (2017) mentions these three competencies: (1) personal (2) managerial, (3) supervision, (4) entrepreneurship, and (5) social competence. Meanwhile, Ross \& Cozzens (2016) explicitly mention leadership, besides other aspects. Furthermore, Rosyada (2004) states that the leadership of madrasa institutions should include the abilities to: (1) create, (2) plan, (3) organize, (4) communicate, and (5) motivate

Based on a research conducted by Sofo, Fitzgerald \& Jawas (2012) in Indonesia, there are often problems faced by school and madrasa headmasters who do not really know their authority in managing educational institutions on the grounds that they are "afraid" to make changes. In the same vein, Silfianti (2013) reported a number of facts about the powerlessness of school headmasters in managing schools, which has resulted in an unconducive climate of learning, negative relationship between headmasters and teachers, unconducive school environment.

A number of researchers conducted studies on the leadership of madrasas. However, their studies are only limited to the leadership of madrasa headmasters in relation to madrasa teachers (Kasidah, Murniati, Bahrun, 2017; Abdulbar, et. al., 2015; Baharun, 2017; Fauzi, 2017; Hajijah \& Mustofa. 2017; Makhromi, 2018; Marhawati, 2017; Manshur, 2017; Maryatin, 2013; Yusnidar, 2014; Setiyati, 2014; Satriadi, 2016). Some studies focused on madrasa headmaster. Maryatin (2013) investigated conceptually the role of madrasa headmaster leadership in improving the quality of Islamic education. Another research was carried out by Abdurrahman \& Firdausi (2019) which focused on headmasters' role in MTS (Madrasab Tsanawiyyah/Islamic Junior high school) Azzainiyah quality control, Probolinggo. However, no study has specifically investigated madrasa headmasters' leadership in relation to madrasa quality improvement.

Speaking about leadership style, some experts, as stated by Burhanuddin \& Umiarso (2012) view that there are several styles of leadership including democratic and authoritarian. Furthermore, modern experts propose other styles of leadership including: managerial, transformational, transactional leadership, and instructional leadership (Bush, 2008; 2015) and positive (Chen, et al., 2016).

Leadership style of madrasa headmasters has been investigated by scholars (Ali, et al., 2015; Gusman, 2014; Muhibbuththabary, 2002; Yusnidar, 2014; Idawati, 2013; Gaol, 2017). However, the studies mentioned focused on headmaster leadership style and its relation with teachers. Other studies investigated leadership styles and its relation to the quality of education. Yusnadi (2016) proposed a conceptual study on headmasters' leadership qualities in the context of school-based management. A similar research was carried out by Sunarni, Kusumaningrum, Benty, (2017) mapping headmasters' leadership style in improving the quality of madrassas. The issue of educational service quality and its relation with headmaster leadership has been studied by Bashori (2016) located in MAN Godean, Sleman Yogyakarta.

No study has specifically investigated madrasa headmasters' leadership in relation to madrasa quality improvement. This study tries to fill the gap. It was aimed at investigating the headmaster's leadership style in improving quality education of madrasa which includes: input, process and output. 


\section{METHOD}

This study is a descriptive-qualitative study using a naturalistic approach. It took place in Maluku Province with samples taken from MAN (Madrasah Aliyah Negeri/State Islamic Senior High School) Ambon City, MAN 1 Tulehu Central Maluku, MTsN (Madrasah Tsanawiyah Negeri/State Islamic Junior High School) Ambon City, MTsN (Madrasah Tsanawiyyah Negeri/State Islamic Junior High School) Tsehawiyah, MTsN Tulehu, MTSN Central Maluku, and MI (Madrasah Ibtidaiyyah/ Islamic Elementary School) Ambon City. The Subjects of this research consisted of five madrasa headmasters and the teacher council in Maluku Province. The data source was determined purposively and this study used snowball sampling when the purposive data sources was not satisfactory. The researchers served as the instruments in this study. Data were collected using techniques namely observation, interviews, and documentation. Data were analysed using the Miles and Huberman model which consisted of data reduction, data presentation, conclusion drawing and verification. To ensure the validity of the data, this study employed several tests namely credibility, transferability, dependability and confirmability test.

\section{RESULTS AND DISCUSION}

\section{Headmasters and Madrasa Quality Improvement}

To describe quality improvement of madrasa education in Maluku Province through the leadership of headmasters, this study uses the following figure 1.

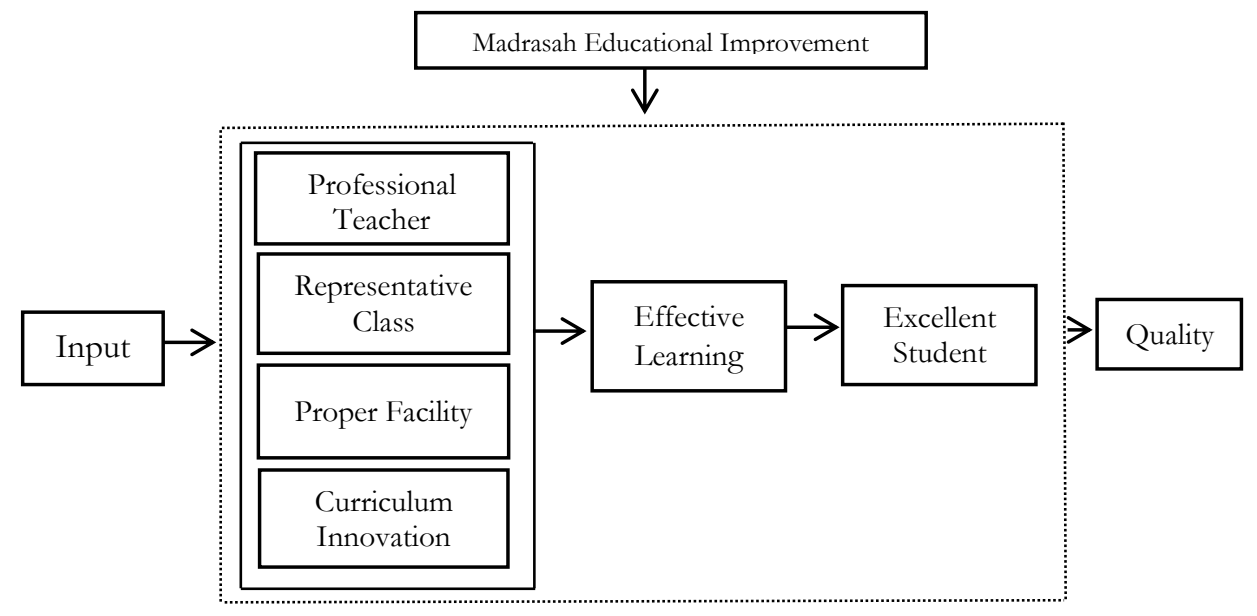

Figure 1. Headmasters' Leadership in Improving Madrasa Education Quality

\section{Input}

Madrasa quality improvement starts from the strategy of obtaining prospective students (input). There are several things that are done by headmasters of madrasa in an effort to recruit prospective students. First, prospective students' selection. Madrasa institutions in the Maluku Province had a policy not charge registration fees to prospective students. This policy, besides being regulated in PPDB (Penerimaan Peserta Didik Baru/Prospective Student Selection) admission guidelines, was also supported by online registration centrally. Based on the observations in the field, this study found that madrasa in Maluku Province had followed the guidelines of 2019 PPDB in recruiting prospective students. Based on these guidelines, PPDB is implemented by online application. The data was corroborated by an interview with the Deputy Headmaster of Madrasah Aliyah (A. Rahmania, Personal Communication, March 3, 2019), that all madrasa institutions were prohibited from accepting fee from new student enrolment. This program has been regulated in PPDB guidelines and at the same time it will 
prevent parents from financial burden on the parts of student guardians. A few years earlier, there were a number of madrassa institutions that had charged registration fees.

Second, competency test. The selection of prospective student admissions was done through a competency test. The test was intended to map the graduation of prospective students according to the students' categories and abilities. It was applied in madrasa institutions in Maluku Province and it included (1) written and (2) oral tests (interviews). It was carried out to obtain a general picture of the prospective students' readiness to attend and learn in madrasa. Based on the interviews with madrasa teachers, this study found that headmasters of madrasa took the initiative to provide prospective students mentoring time under the guidance of expert teachers to improve prospective student competency (M. Fathoni, Personal Communication, March 3, 2019).

\section{Process}

The improvement of madrasa institutions in Maluku Province has been done through the process of learning. It should be achieved through several strategies.

\section{Strengthening Human Resources Professionalism}

Madrasa education quality improvement depends on the human resources (HR) of teachers who are at the forefront of learning activities. The headmasters in Maluku Province underlined the teachers' role because they were the determining factor for the success of learning activities in the classroom. Teachers should be set as a priority in improving the quality of madrasa education.

In connection with the leadership aspects of headmasters in madrasa, there were several attempts taken headmasters to strengthen human resource professionalism of teachers. First, they put pressure on the part of the teachers to improve their competence and professionalism. In an effort to support this attempt, the headmasters had allocated a number of teachers to take part in competency tests and in-service teacher training through the PLPG (Pendidikan dan Latiban Profesi Guru/Teacher Profession Training Development and Education) program each year. Based on the observations, this study found that the headmaster had organized training activities to increase teachers' competency in madrasa every year, especially for the teachers who had not been certified. This study interviewed the Headmaster of MI Ambon City (N. Marasabessy, Personal Communication, March 23, 2019) who confirmed that teachers who had not been certified were encouraged to attend competency improvement training. The same thing was explained by the teacher from MIN Ambon (N. Pattilauw, Personal Communication, March 23, 2019) who explained that teachers who had not yet received professional teacher certification were encouraged by the headmaster to participate in a teacher competency improvement training program.

Second attempt was to provide opportunities for the teachers to take part in various activities that can improve their competence, such as workshops, seminars, training, and so on. This study observed that madrasa teachers in Maluku Province were actively involved in scientific activities that can improve their competency. Some teachers were actively involved in learning design training activities, the use of active learning strategies, the application of learning evaluation, the use of instructional media based on information technology (IT), and others. Their activities were proven by the form of certificates. This study interviewed teachers from MTsN Ambon (J. Namakule, Personal Communication, March 17, June 20, 2019) who confirmed that their headmasters had strong vision and mission to improve teachers' professionalism in Maluku Province and motivated them to participate in scientific activities, especially those held in halls training or higher education institutions providing training for teacher competency improvement. 
Third attempt was the application of the rules in advancing madrasa achievement based on the rules that applied in madrasas. The headmaster of madrasas in Maluku Province ensured themselves to carry out the vision and mission of the madrasas with their programs. Based on the observation, the headmaster of madrasas in Maluku Province had the ability to organize, distribute tasks and responsibilities fairly. They were able to make decisions appropriately, always be happy in facing difficulties, able to recognize work that has been completed and perfectly done. The results of interviews with the teachers from MAN Ambon (M. Fathoni, Personal Communication, March 3, 2018) who emphasized that the madrasa headmasters had the ability and competency in managing madrasas, so teachers must follow these rules properly.

Fourth attempt was to provide a representative class. The representative class in this study refers to a suitable class to be used for learning activities that are equipped with a whiteboard, a marker, an eraser, and an in focus. Those equipments give a sense of comfort in learning activities. In a number of MA, classes with in focus facilities had been installed and could be used properly. In terms of air conditioner, no class applied it because generally, madrassa in Maluku Province are in cold temperatures.

Fifth attempt was to Provide Complete Facilities. In accordance with the madrasa strategic plan, education and learning facilities are the concern of the headmasters in improving madrasa quality. The headmasters had allocated adequate facilities in several stages and were regularly evaluated. Teachers were involved in evaluating the provision of this facility so that the shortcomings occurred can be spotted and evaluated throughout the madrasa community. Based on the results of observation, madrasa institutions were able to provide their own facilities like computer laboratories, language laboratories, practice rooms, madrasa libraries, and etc.

Based on the observation, this study found that computer, language, and science laboratories, had been owned by a number of MA. Computer laboratories were used for introducing computer-based technology that can be used to find information for learning materials in madrasa. Computer laboratories were also used for administering the written tests for college entrance online. This study interviewed teachers from MAN Ambon and Tulehu (J. Sarwoed, Personal Communication, April 4, 2018) who confirmed that their headmasters aspired to become a pilot project for information technology development in Maluku. The same assertion was stated by the headmaster MTsN Ambon State (K. H. Umar, Personal Communication, march 14, 2019) who stated that the industrial era 4.0 "forced" students to have literacy in technology, so that the headmasters channelled funds to fulfil the needs of a computer laboratory.

The language laboratories have been a dire need for language learning in MA. This study observed that the headmasters had allocated funds to meet the needs of language laboratories for student's language learning. Laboratory programs were arranged according to needs, especially for the highest grade. This study interviewed the headmaster of MAN Tulehu $(N$. Marasabessy, Personal Communication, April 2, 2019) who confirmed that the headmaster had instructed the use of language laboratories to benefit students. Language programs provided included Arabic and English language programs

The headmasters had designed the madrasa library activities which were aimed at broadening students' knowledge. They had assigned certain teachers or certain staff to work and serve students at library. However, based on observations, some madrasa libraries had not been professionally managed. The results of interviews with the teacher from MIN Ambon (N. Pattilauw, March 23, 2019) who expressed that so far, the library had not been well managed. 


\section{Establishing Curriculum Innovation}

The headmasters encouraged teachers to apply the applicable curriculum in the Ministry of Religion of the Republic of Indonesia. The 2013 curriculum has been updated using a thematic learning approach. The 2013 curriculum had received full support from the headmasters. The headmasters encouraged teachers to be actively involved in curriculum innovation by utilizing teacher working groups through FGD (Focus Group Discussion). The observation results show that discussion group forums were available in every madrasa unit, ranging from MI, MTs and MA. This was also confirmed by the Deputy Headmaster of MA for Curriculum the innovations led by headmasters were aimed at adapting and elaborating the curriculum to be relevant to the level of thinking and acceptance of students (S. Soulissa, Personal Communication, April 4, 2019).

\section{Establishing Effective Learning Time}

The headmasters and team had developed an effective learning program at the madrasa. The learning program was outlined in the work papers of madrasa headmasters and implemented in a committed manner by the teachers. Based on observations, this study found that effective learning time could create an academic culture of madrasas and encourage students to learn seriously. This study of interviewed the headmaster of MI Ambon City (N. Marasabessy, Personal Communication, March 23, 2019), who emphasized that students' learning effectiveness were very dependent on conducive learning climate provided by madrasa. The headmaster created this effective learning time to show respect and to achieve educational goal service.

\section{Output}

The quality of madrasa education can be seen from the outputs of the graduates. One of its quality can be seen from the number of students graduating in the final exam. The student percentage who have been accepted in their next level for example from MI to MTs will determine the quality of madrasa education. Based on a review of madrasa graduation documentation in Maluku Province, this study found that $100 \%$ of madrasa students in Maluku Province had graduated. To be fair, madrasa quality education can be viewed from some indicators namely UN (Ujian Nasional/National Test) or UAMBN (Ujian AKbir Madrasah Berstandar Nasional/National Standard for Madrasa Final Examination). This study found that the graduates had passed the test and their academic performance were on average for the tests.

In addition, to maintain the madrasa quality and achievements, headmasters used accreditation guidelines as their framework. Five madrasas in Maluku Province that were sampled in this study had been accredited based on BANSM (Badan Akreditasi Sekolab madrasab/School and Madrasa Standards National Accreditation Board). To improve their quality, the accreditation board had recommended that madrassas pay attention to a number of things: (1) organizational structure, (2) management guidelines, (3) standard operating procedures, (4) work programs.

There are a number of steps taken by headmasters of madrassa institutions in Maluku Province in preparing for the UN or UAMBN. For example, providing intensive guidance on a subject tested. This was done by using as test material for exercise given beyond regular learning activities. It was carried out under the guidance of subject teachers. Based on the observations, this study found data that there were some students who intensively participated in the program of IPA (Ilmu Pengetahuan Alam/Nature science) intensive learning. Most of the students took a part in all subjects tested. Other students focused on Arabic and SKI (Sejarah Kebudayaan Islam/Islamic cultural history) intensive learning. This study interviewed the Deputy headmaster of MI (Masduqi, Personal Communication, March 23, 2019) who 
confirmed that intensive learning to prepare for the test had improved the quality of madrasa education in Maluku Province.

\section{Leadership Style of Headmasters and Madrasa Quality Improvement}

Madrasa quality can be associated with the headmaster's style of leadership. Headmasters' leadership style entails their interactions with their teachers in implementing learning tasks in madrasa. There are three aspects that can be applied to examine the headmasters' leadership style related to the task of the teachers in improving the quality of madrassas. The leadership style includes aspect of headmasters' ability to increase: teacher commitment and responsibility, teacher motivation, and teacher discipline.

\section{Headmaster's Leadership Style in Strengthening 'Teachers' Commitment and Responsibility}

Headmasters and teachers should be a harmonious partner in achieving the vision and mission as well as the madrasa program. On the one hand, the headmasters design a work program according to their capacity as a thinker, leader, organizer, and evaluator of the madrasa work system. On the other hand, teachers have the responsibility to plan, execute, and evaluate learning activities in their classes. Both parties must commit to deliver educational service and to improve the quality of education. Based on observations, this study found that the headmasters in the Maluku Province had a high commitment in accomplishing their duties. This can be seen from their work productivity that had generated appreciation from the community on their dedication and loyalty to improve educational service. They are also expected to be good figure, uswah, and guardian of commitments in maintaining quality educational service. Some problems occurred on the part of the teachers since some of the teachers exhibit low commitment. Headmasters in this circumstance were in the position to invite them for discussion to motivate them to work.

Conducting personal communication with the teachers was a possible option for the headmaster. This communication was aimed at solving the urgency of the task in achieving the vision and mission of madrasa. Some problems occurred related to teachers' professionalism. For example, teachers who had difficulty in preparing lesson plans, they were encouraged to discuss with their peers. Teachers also had challenge related to their' weak mastery to develop teaching materials. Therefore, they were given assistance from the deputy of headmaster to cope with the problem.

Based on the observations, the headmasters in Maluku Province generally applied subordinate-oriented leadership. This was evident from their activities that motivate the teachers to work more, to involve in making decisions, and to develop cooperative relations. This study interviewed the teacher from MTsN Ambon City (J. Namakule, Personal Communication, March 17, 2019) who confirmed that headmasters always communicated and involved the teachers in making every decision related to madrasa programs and commitments.

The study interviewed the teachers from MI Ambon City Madrasab Ibtidaiyah teachers (N. Pattilauw, Personal Communication, March 23, June 2019) who also confirmed that the headmasters always emphasized the commitment to jointly build the quality of madrasa. The teachers' performance was monitored by the headmasters to ensure that it was in line with the vision and mission of the madrasa. If there were problems among the teachers, the headmaster did not hesitate to engage in dialogue with the them. Given this style of leadership, the headmaster can be said to apply democratic leadership. The headmasters had placed their teachers and other parties as their partners in dialogue and problem solving. 


\section{The Headmasters' Leadership Style in Boosting Teacher Motivation}

Madrasa quality is related to the enthusiasm and spirit of the teachers in carrying out the task of teaching and learning activities. Their spirit and enthusiasm need to be encouraged so that their commitment can improve the quality of madrasa. Based on the observations, the headmasters in Maluku Province had shown high working motivation. They worked with enthusiasm and passion. Before they returned home, they also had checked teachers who still had work, and students who had additional activities. To ensure learning activities in the classroom, they often visit classes during study hours.

The headmasters were also accustomed to attend meeting with the teachers in the teacher's room. They promoted warmth atmosphere as well as professionalism. Their leadership can be seen from their ability to communicate with all teachers, both formally and informally. They were open to complaints, criticism and suggestions in oral and written form, inside and outside the madrasa environment. This step was administered to explore the problems faced by teachers in carrying out the task of the madrasa. They tried to map the problems sought to find a solution.

This study interviewed the headmaster of MA Ambon (S. Mahubessy, Personal Communication, March 2, 2019) who confirmed that the headmaster intentionally applied communication formally and informally to motivate the teachers in carrying out their duties. The communication was designed to explore the feelings and needs of the teachers in Maluku Province. The headmaster strived to build family characteristics relationship to foster a conducive work climate and improve the teachers' work productivity in the future. In the same vein, the teachers from MA Ambon City (J. Sarwoedi, Personal Communication, April 4, 2019) expressed in an interview that the headmaster administered open communication which led to the teachers' enthusiasm and motivation to work and to improve the quality of the madrasa education. Based on the observations, this study found that the headmaster had a regular visit to the teacher's office. The headmaster promoted a collegial relationship. This means that the headmaster was obliged to monitor and assist the teachers' activities. This relationship brought benefits for both parties. The headmaster did not feel "patronizing" or "dictating" the teachers in carrying out their duties. On the other hand, the teachers felt that the headmaster cared for them. As a result, the teachers' spirit of work improved and they were able to serve quality of learning for their students. Viewed from this aspect, the headmaster of madrasas in Maluku Province developed a democratic leadership style.

\section{The Headmasters' Leadership Style in Improving Teacher Discipline}

The headmasters in Maluku Province were committed to upholding time and work discipline. Based on the observations, this study found that the headmaster strived to set good example and the role model in enforcing time and work discipline. The headmasters came to the office and returned home as scheduled. In MA Tulehu and MA Ambon, the headmasters had a special staff who oversaw the teachers' discipline. Teachers who violated discipline were given sanctions including intensive coaching. This study interviewed the teacher from MAN Tulehu (J. Sarwoedi, Personal Communication, April 4, 2019) who confirmed that every teacher who arrived late or left the class were regularly reprimanded by the headmaster. Viewed from this aspect, the headmaster in Maluku Province developed an authoritarian leadership style.

Based on the findings of this study concerning the headmasters' leadership style, the emphasis can be attached to the leadership as a form of persuasion to a groups of people, usually through "human relations" and the right motivation so that people in an organization want to cooperate, understand and achieve all the goals of the organization (Purwanto, 2007). The essence of leadership is one's personality (authority) that is used as a means of convincing the persons led so that they want and can carry out the tasks assigned to them willingly, 
passionately, and does not feel forced. The key to the leadership lies on leaders' ability to carry out their skills related to the party they lead. The central role of leadership in madrasa institutions provides an opportunity for headmasters to continue to hone the dimensions of leadership that are complex (Burhanudin \& Umiarso, 2012)

There are five things related to the leadership of headmasters in improving the quality of madrasa education. First, the headmasters should have the ability to create, offer good ideas, obtain solutions to various problems commonly faced by madrasa. They are expected to be able to on the one hand, identify the consequences of implementing various decisions. On the other hand, they are required to use their ability of imaginative thinking (lateral thinking) to connect things with others. They can solve this problem by gradual provision for the facilities in madrasa. It is expected that leadership style can improve teacher performance in teaching and learning (Octavia, 2016).

Second, the headmasters should have the ability to make plans; connect the present and tomorrow's realities. Their ability can be seen from their work papers, documented work programs and work outcomes. They should demonstrate their vision in answering various problems by finding solutions to offer (Rosyada, 2004; Munir, 2008). In addition, they should be able to map madrasa activities and organize plans for each year to improve administrative services, learning technology, environmental management and problem solving. Applying task-oriented leadership, the headmasters pay great attention to the tasks of subordinates and tend to emphasize the technical aspects (Gusman, 2014)

Third, the headmasters should have the ability to organize; distribute tasks and responsibilities fairly, make decisions appropriately. Furthermore, they are expected to express a happy attitude in dealing with difficulties, recognize and appreciate the work that has been completed and perfectly done. Some headmasters carry out activities based on the main tasks and functions of each person, in accordance with job description and expertise of people. other headmasters make decisions based on priorities and establish networking with various groups (stakeholders). In this context, the headmasters sometimes implement work-oriented (task) leadership.

Fourth, the headmasters should have the ability to communicate; understand others, listen to others, explain things to others, communicate through writing, make other people talk, encourage others to go forward and always follow and utilize technology information. This study found that the headmasters in Maluku Province were very respectful of the needs and problems of their subordinates. They should embrace the principle of tut wuri bandayani, and keep motivating their teachers to be creative and innovative. In this context, they applied a leadership style that is oriented towards humanity (subordinates) because it can create an atmosphere of good human relations.

Fifth, the headmasters should have the ability to motivate; inspire others, deliver realistic challenges, help others to achieve their goals and targets, help others to assess their own contributions and achievements. In this study, the headmasters had shown their ability to provide policies that always demand quality improvement. They also gave opportunities to their teachers to improve their professionalism through workshops, seminars, training and empowerment of the role of discussion group forums. In addition, they expressed their empathy for the madrasa, always followed the development of information from various media, were open to criticism, were able to use the internet in accessing information, and appreciated every madrasa's work.

Taking into account the leadership style used by the headmasters in this study, some headmasters used the managerial leadership style as stated by Bush (2008). Managerial leadership appears to be more focused on everything that can be managed properly. Bush (2015) states that "managerial leadership assumes that the focus of leadership ought to be on 
functions, tasks, and behaviours and if these functions are carried out completely, the work of others in the organization will be facilitated" Leadership with this managerial style requires every part of the madrasa organization is correctly positioned so that the objectives of the madrasa are achieved. There is a weakness from this managerial leadership definition since it does not include the concept of vision (Bush, 2008).

Managerial leadership style which is adopted by the headmasters has a positive impact on madrasa institutions. The headmasters' ability to organize programs brought a positive educational atmosphere which was not boring for both the teachers and students in the madrasa environment. In addition, this style can have a positive impact on teachers' satisfaction in madrasas. In line with this, Silfianti (2013) conducted research on headmasters' managerial competency. This competency contributed positively to the motivation of teacher work. When the teacher's work motivation gets better, the teacher has a better performance in educating and establishing social relations with the teacher and other educational staff. The positive contribution of the headmasters' managerial leadership style to the motivation of teacher performance can lead to an increase in school effectiveness because teachers have enthusiasm and loyalty to the school (Burhanuddin, et. al., 2016; Gusman, 2014)

Some headmasters in this study performed transformational leadership. The main focus of this style is that the headmasters finds influential activities and outcomes (Bush, 2008). According to Northouse (2013), there are five important factors related to transformational leadership, namely: (1) ideal influence, (2) charisma, (3) inspirational motivation, (4) intellectual stimulation, and (5) adaptation considerations. The headmasters displaying these factors were expected to be wiser in their acting and dealing with teachers and education staff in the madrasa environment. They tend to adopt a democratic approach to their leadership style (Giltinane, 2013). By implementing transformational leadership well, the headmasters have the potential to involve stakeholders in achieving educational goals (Bush, 2015). They should be able to involve teachers, educational staff, and parents of students so that they play an active role in developing school effectiveness. Satriadi (2016) asserted that teacher performance can be influenced by several factors: (1) personal factors, level of skills possessed, motivation, and individual commitment, (2) leadership factors, quality of encouragement, feedback and support from managers and team leaders, (3) team factors, the quality of support provided by colleagues, (4) system factors, work systems and facilities provided by the organization, and (5) contextual situational factors, pressure levels and environmental changes (internal and external).

In Indonesia, this transformational leadership style should be performed by the headmasters because it allows more and more creative ideas and innovations to grow from various parties (Kasidah, et. al., 2017). All human resources in madrasa should be wellmanaged (Jones \& Walters, 2008) This is in line with experts' views promoting effective transformational leadership to be implemented between leaders and subordinates (Giltinane, 2013). The headmasters who apply transformational leadership style play a role in encouraging school development (Yang, 2014). The headmasters in this context are required to be able to build trust from teachers and education staff so that the headmasters are able to develop their leadership and responsibilities. In addition, they must share the madrasa vision and mission with the stakeholders so that they can create a conducive atmosphere for learning and improve madrasa quality. This will ensure the quality of education to sustain (Thangeda, 2016).

The instructional leadership style consists of special and general concepts $(\mathrm{Ng} \&$ Nguyen, 2015). The former defines instructional leadership as actions that are directly related to teaching and learning processes. The headmasters directly observe the classroom. The later, defines instructional leadership as an act of leadership that indirectly influences student learning. In this study, the headmasters conducted program in creating culture and effective 
timing in madrasas. Hallinger \& Murphy (1985) as the main experts who developed the concept of instructional leadership proposed 10 important aspects of instructional leadership, namely: (1) framing the school's goals, (2) communicating the school's goals, (3) coordinating the curriculum, (4) supervising and evaluating instruction, (5) monitoring student progress, (6) securing instructional time, (7) providing incentives for teachers, (8) providing incentives for learning, (9) promoting professional development and (10) maintaining high visibility. Applying this instructional leadership, the headmasters must be able to be the initiator and facilitator to ensure that teaching and learning process run well in the school. They are expected to be able to create an organizational culture in the madrasa as conducive as possible so that students' learning achievement and teacher performance can improve.

Other style of leadership is positive leadership. This study found that the headmaster in Maluku Province were able to implement positive leadership. According to Chen, et al. (2016) stated that positive leadership is a type of leadership that deals with a variety of things by involving positive thinking so that situations that are forgiving, sympathetic, and loving are manifested. In addition, this type of leadership strives to support one another among members so that they care for one another and love one another to create positive relationships at work. Chen, et. al., (2016) reported that positive leadership is significantly associated with school effectiveness mediated by the culture of school organizations. The urgency of a positive-thinking leader is very supportive in creating a conducive school environment. The headmaster in this context is demanded to do the right thing and have optimism. The application of a positive leadership style is considered important by the headmaster of madrassas in Indonesia, including in Maluku. The madrasa head is demanded to be able to have a positive mindset so as to create a conducive and democratic madrasa atmosphere so that the madrasa can be realized effectively. A democratic climate can also be supported by the implementation of school-based management (Mulyasa, 2012).

This study found that the headmaster of madrasas in Maluku Province had exercised situational leadership. They took into consideration input, process and output in madrasa education. The application of various leadership styles should be adjusted to context where they are implemented. A number of studies have reported this issue. Ali, Harun, Djailani, (2015) conducted research located in Lambaro Angan State Elementary School. The study reported that the leadership style that stands out in that location is a task-oriented and subordinate leadership style. Headmasters who adopt a task-oriented leadership style pay great attention to the tasks of subordinates and tend to emphasize technical aspects. Headmasters who apply this leadership style motivate subordinates rather than supervise them. They sometimes apply subordinate-oriented leadership. They motivate the teacher in working, engage the teacher intheir work, their decision making, and their cooperative relationships.

Muhibbuththabary (2002) conducted a research on madrassas in Aceh related to the leadership style of madrasa principals. The study reported that leadership styles that develop in Aceh are selling and telling leadership. Applying selling style, the headmasters gives instructions and decides dominantly. This leadership style in its implementation uses two-way communication and provides support to subordinates, listening to subordinates' complaints about the decisions taken by the headmasters. In a telling style, the headmasters are more dominant, and unilaterally the madrasa head determines all decisions. The selling leadership style is not prominent. This confirms that a number of studies on the leadership style of madrasas in Indonesia generally apply a situational leadership style.

Research on the leadership of madrasa leaders in Maluku Province is important to do to improve the quality of madrasa education in Maluku Province. However, this research has not yet reached madrasas in other districts/cities in Maluku Province. Leadership of the madrasa head who influences the quality of madrasa education can also be carried out in other 
madrasas in Indonesia. A number of madrasa leaders in Indonesia have not fully realized their enormous authority in developing and enhancing the quality of madrasa.

\section{CONCLUSION}

This study was aimed at exploring the headmaster leadership style and its role in improving the quality education of madrasa. Based on the result and discussion, some conclusion can be drawn. The headmasters' leadership in this study improved madrasa quality in Maluku Province. The quality of madrasa education refers to three aspects namely: input, process and output. The input aspect relates to the strategy of selecting prospective student admissions. The headmaster applied strategic steps by administering competency tests for prospective students. It was aimed at mapping and placing prospective students. Process aspects related to the implementation of coaching and guiding classroom learning. This involved the provision of professional teachers, representative classes, complete facilities and innovative curriculum. For the teachers, their headmasters in Maluku Province had treated them in improving their commitment and responsibility, motivation, and discipline. The headmasters in this study had the ability to communicate, understand others, innovate in achieving madrasa quality. Meanwhile, the output aspect in this study can be measured by the number of madrasa graduate in Maluku Province whose grades were above the average results of UAMBN and UN. The Headmasters maintained their madrasa reputation and quality by following the guidelines from BANSM.

The leadership style had been applied by headmasters in Maluku Province. The headmasters implemented managerial leadership when they focused their leadership on everything in order to be well managed. Some headmasters applied instructional leadership when they focused on actions that were directly related to teaching and learning. They also featured transformational leadership when their main focus was to find influential activities and outcomes. This leadership was more prominent in every madrasa because it put forward a democratic approach. The headmasters were able to involve teachers, education staff and parents of students so that they played an active role in developing school effectiveness.

\section{BIBLIOGRAPY}

Abdulbar, et. al., (2015). "Kepemimpinan Kepala Madrasah dalam Meningkatkan Profesionalisme Guru pada MAN Ngabang Kabupaten". Jurnal Pendidikan dan Khatulistiwa, 4(6). Januari, 320-349. Retrieved from http://jurnal.untan.ac.id/index.php/ jpdpb/article /view/10334

Abdurrahman \& Firdausi, A. (2019). "Peran Kepemimpinan Kepala Madrasah dalam Pengendalian Mutu: Studi Kasus Di MTS Azzainiyah 1 Paiton, Probolinggo". Jurnal al-Fikrah. VII(1), 1-10. http://doi.org/10.31958/jaf.v7i1.1269

Ali , S. N. M., Harun, C. Z., Djailani A. R. (2015). "Gaya Kemimpinan Kepala Sekolah dalam Meningkatkan Kinerja Guru pada SD Negeri Lambaro Angan”. Jumal Administrasi Pendidikan.3(2), 116-127. Retrieved from http://erepository.unsyiah.ac.id/JAP/article/view/2566/2425

Baharun, H. (2017). "Peningkakan Kompetensi Guru melalui Sistem Kepemimpinan Kepala Madrasah". Al-Tajdid: Jurnal Ilmu Tarbiyah, 6(2), 1-25. Retrieved form http://ejournal.stitmuhpacitan.ac.id/index.php/tajdid/article/download/38/51

Bashori. (2016). "Gaya Kepemimpinan Kepala Madrasah dalam Meningkatkan Mutu Layanan Pendidikan: Studi Kasus di MAN Godean Sleman Yogyakarta". Ta'dib, V(1), 19-28. https://doi.org/10.29313/tipi.v5i1.1978 
Burhanuddin, et. al., (2016). "Profesionalisme Kepemimpinan Kepala Sekolah dalam Meningkatkan Mutu Pendidikan di SMA Negeri 4 Wira Bangsa Meulaboh Kabupaten Aceh Barat", Jurnal Magster Administrasi Pendidikan, 4(1). 72-81. Retrieved from http://www.jurnal.unsyiah.ac.id/JAP/article/view/2609/2463

Burhanudin \& Umiarso. (2012). Kepemimpinan Pendidikan Islam: Teori dan Praktek. Yogyakarta: Ar-Ruz Media.

Bush, T. \& Glover, D. (2014). "School Leadership models: What we do know?". School Leadership \& Management, 34 (5), 553-571.

Bush, T. (2008). Leadership and Management Development. London: SAGE Publication Ltd.

Bush, T. (2015). "Organisation Theory in Education: How does in inform school leadership?". Journal of Organizational Theory in education, 1 (1), 35-47. Retrieved from http://web.stanford.edu/group/ojs-jote/cgi-bin/ojs2/index.php/jote/article/view/19

Chen, C., Tsai S., Chen, H., \& Wu, H. (2016). "The Relationship between the Principal's Positive Leadership and School Effectiveness-Take School Organizational Culture as The Mediator". European Journal of Psychological Research. 3 (2), 12-23.

Fauzi, A. (2017). "Kepemimpinan Kepala Madrasah dalam Mengembangkan Lembaga Pendidikan Islam". Nidhomul Haq. 2(2), 53-64. https://doi.org/10.31538/ndh.v2i2.22

Gaol, N. T. L. (2017). "Teori dan Implementasi Gaya Kepemimpinan Kepala Sekolah". Kelola Jurnal Manajemen Pendidikan. 4(2), 213-219. https://doi.org/10.24246/ j.jk.2017.v4.i2.p213-219

Giltinane, C. L. (2013). Leadership Style and Theories. Nurshing Standard. 27 (41), 35-39.

Gusman, H. E, (2014). "Hubungan Gaya Kepemimpinan Kepala Sekolah dengan Kinerja Guru di SMPN Kecamatan Palembayan Kabupaten Agam”. Bahana Manajemen, Jurnal Administrasi Pendidikan, 2(1), 293-831. https://doi.org/10.24036/bmp.v2i1.3764

Hajijah \& Mustofa, A. (2017). "Kepemimpinan Kepala Madrasah dalam Inovasi Mana-jemen Pendidikan Di Mts N Diwek Jombang. Al-Idaroh. 1(1) Maret, 138-161. Retrieved from https://jurnal.stituwjombang.ac.id/index.php/al-idaroh/article/view/12

Hallinger, P., \& Murphy, J. (1985). "Assessing the Instructional Leadership Behavior of Principals". Elementary School Journal. 86 (2), 217-248. http://dx.doi.org/10.1086/461445

Idawati. (2013). "Gaya Kepemimpinan Kepala Sekolah dan Kinerja Guru". Jurnal Eklektika. 1(2), 153-162. Retrieved from https://ojs.unm.ac.id/Eklektika/article/view/5654

Idris, R. (2009). "Pendekatan Pendidikan Berbasis Mutu", Lentera Pendidikan. 12(1), 103-123.

Jones, J. J. \& Walters, R. L. (2008). Human Resources Management in Education: Manajemen Sumber Daya Manusia dalam Pendidikan. Yogyakarta: Q-Media.

Kasidah, Murniati, A. R., Bahrun. (2017). "Kemimpinan Kepala Sekolah dalam Meningkatkan Kinerja Guru pada Sekolah Dasar Luar Biasa Negeri Banda Aceh", Jurnal Administrasi Pendidikan. 5(2), 127. Retrieved from http://www.jurnal.unsyiah.ac.id/ $\mathrm{JAP} /$ article/view/8362

Makhromi. (2018). "Peran Kepemimpinan Kepala Madrasah dalam Meningkatkan Kualitas Pendidikan di Madrasah Aliyah". 29(1), 66-84.

Marhawati, B. (2017). 'Kepemimpinan Kepala Sekolah Perempuan pada Sekolah Efektif'. Jurnal Manajemen dan Supervisi Pendidikan. 1(2), 12-127.

Manshur, A. (2017). "Peran Komite Madrasah dan Kepemimpinan Kepala Madrasah dalam Meningkatkan Mutu Pendidikan Islam". At-Tubfah: Jurnal Keislaman. 6(1), 34-48. Retrieved from http://ejournal.sunan-giri.ac.id/index.php/at-tuhfah/article/view/80

Maryatin. (2013). "Peran Kepemimpinan Kepala Madrasah dalam Meningkatkan Mutu Pendidikan Islam". Mudarisa: Jurnal Kajian Pendidikan Islam. 5(2), 195-221. https://doi.org/10.18326/mdr.v5i2.195-221 
Maswan. (2015). "Manajemen Peningkatan Mutu Sekolah". Jurnal Tarbawi, 12(2), 193-204. https://doi.org/10.34001/tarbawi.v12i2.514

Muhibbuththabary. (2002). "Gaya Kepemimpinan Kepala Madrasah dan Efektivitas Pendidikan”. Istiqra': Jurnal Penelitian Sosial Keagamaan, 1(1), 91.

Mulyasa, E. (2012). Manajemen Berbasis Sekolab: Konsep, Strategi, dan Implementasi. Bandung: Remaja Rosdakarya.

Munir, A. (2008). Menjadi Kepala Sekolah Efektif. Yogyakarta: Ar-Ruzz Media.

Ng, F. S. D., Nguyen, et. al., (2015). "Instructional leadership practices in Singapore". School Leadership \& Management. 35 (4), 388-407.

Northouse, P. G. (2013). Kepemimpinan: Theori dan Praktik. Jakarta: PT. Indeks.

Octavia. L. S. 2016. "Gaya Kepemimpinan Kepala Sekolah dalam Upaya Meningkatkan Kinerja Guru dan Tenaga Kependidikan". Jurnal Dinamika Manajemen Pendidikan. 1(1), 714.

Purwanto, N. M. (2007). Administrasi dan Supervisi Pendidikan. Bandung: PT. Remaja Rosdakarya.

Ross, D. J. \& Cozzens, J. A. (2016). The Principalship: Essential Core Competencies for Instructional Leadership and Its Impact on School Climate". Journal of Education and Training Studies. 4 (9), 162-176.

Rosyada, D. (2004). Paradigma Pendidikan Demokratis. Jakarta: Prenada Media. 2004.

Satriadi. (2016). "Pengaruh Kepemimpinan Kepala Sekolah terhadap Kinerja Guru”. Jurnal Benefita. 1(3) Oktober. 123-133.

Silfianti. (2013). Kontribusi kompetensi manajerial kepala sekolah terhadap motivasi kerja guru SMP Negeri di Kecamatan Padang Timur", Jurnal Bahana Manajemen Pendidikan. 1 (1), 220-461. https://doi.org/10.24036/bmp.v1i1.2699

Sofo, F., Fitzgerald, R., \& Jawas, U. (2012). "Instructional Leadership in Indonesian School Reform: Overcoming the Problems to Move Forwad". School Leadership and Management. 32 (5), 503-522.

Setiyati, S. (2014). "Pengaruh Kepemimpinan Kepala Sekolah, Motivasi Kerja, dan Budaya Sekolah Terpadu terhadap Kinerja Guru”. Jurnal Pendidikan Teknologi dan Kejuruan. 22(2). https://doi.org/10.21831/jptk.v22i2.8931

Sunarni, Kusumaningrum, D. E., Benty, D. D. N. (2017). "Pemetaan Gaya dan Tipe Kepemimpinan Kepala Sekolah". Jurnal Sekolah Dasar: Kajian Teori dan Praktik Pendidikan. 26(1), 19-29. http://dx.doi.org/10.17977/um009v27i12018p019

Thangeda, A .2016. "Education for Sustainability: Quality Education Is a Necessity in Modern Day. How Far do the Educational Institutions Facilitate Quality Education?". Journal of Education and Practice, 7(2), 9-17.

Wiyoto, B. B. (2017). "The Effect of Selfevaluation on the Principals' Transformational Leadership, Teachers' Work Motivation, Team-work Effectiveness, and School Improvement". International Journal of Leadership in Education, 1-21.

Yang, Y. (2014). "Principal's Transformational Leadership in School Improvement". International Journal of Educational Management, 28 (3), 279-288.

Yusnadi. (2016). "Tipe dan Gaya Kepemimpinan Kepala Madrasah dalam Manajemen Berbasis Sekolah". Ittihad: Jurnal Kopertais Wilayah XI Kalimantan, 14(25), 91-100. http://doi.org/10.18592/ittihad.v14i25.866

Yusnidar. (2014). "Kepemimpinan Kepala Madrasah dalam Meningkatkan Kinerja Guru pada MAN Model Banda Aceh". Jurnal Ilmiah Didaktika. 14(2), 320-349. http://dx.doi.org/10.22373/jid.v14i2.506 